\title{
OVERSTORY-IMPOSED HETEROGENEITY IN SOLAR RADIATION AND SOIL MOISTURE IN A SEMIARID WOODLAND
}

\author{
David D. Breshears, ${ }^{1}$ Paul M. Rich,${ }^{2}$ Fairley J. Barnes,${ }^{1}$ And Katherine Campbell ${ }^{3}$ \\ ${ }^{1}$ Environmental Science Group, Mail Stop J495, Los Alamos National Laboratory, Los Alamos, New Mexico 87545 USA \\ ${ }^{2}$ Department of Systematics and Ecology, Environmental Studies Program, and Kansas Biological Survey, \\ University of Kansas, Lawrence, Kansas 66045 USA \\ ${ }^{3}$ Geoanalysis Group, Mail Stop F665, Los Alamos National Laboratory, Los Alamos, New Mexico 87545 USA
}

Abstract. Degradation of semiarid ecosystems is a major environmental problem worldwide, characterized by a reduction in the ratio of herbaceous to woody plant biomass. These ecosystems can be described as a set of canopy patches comprising woody plants and the intercanopy patches that separate them, yielding an overstory with intermediate closure. Field measurements of microclimate at the scale of canopy patches, particularly for near-ground solar radiation and soil moisture, are largely lacking from both nondegraded and degraded ecosystems. We tested for relationships among spatial patterns of the overstory, near-ground solar radiation, and soil moisture in a semiarid piñon-juniper woodland in northern New Mexico that had a highly heterogeneous overstory ( $\approx 50 \%$ canopy cover) and was not degraded with respect to ground cover and erosion rates. We used measurements taken every $1 \mathrm{~m}$ along a 102-m transect-solar radiation indices were estimated monthly and annually using hemispherical photographs, and soil moisture was measured over 4 yr using time-domain reflectometry (TDR) - and analyzed the data using general least squares linear models that accounted for spatial autocorrelation and temporal heteroscedasticity.

Time-averages of solar radiation and of soil moisture both were spatially autocorrelated at scales of up to $4 \mathrm{~m}(P<0.05)$, corresponding approximately to the average lengths of both canopy and intercanopy patches and to the scale of spatial autocorrelation in the canopy/intercanopy pattern of the overstory $(3 \mathrm{~m} ; P<0.05)$. For near-ground solar radiation, we found expected spatial variation between patches (canopy $<$ intercanopy; $P<$ 0.0001 ) and within patches for centers vs. edges (canopy center $<$ canopy edge and intercanopy center $>$ intercanopy edge; $P<0.0001$ ) and for north vs. south edges (canopy north edge $<$ canopy south edge and intercanopy south edge $<$ intercanopy north edge; $P$ $<0.0001)$. For soil moisture, canopy locations were significantly drier than intercanopy locations $(P<0.0001)$, and edge locations were significantly wetter than center locations both overall and within both patch types $(P<0.0001)$. Spatial heterogeneity in soil mositure was attributed primarily to canopy interception and drip on the basis of large differences in snow cover between canopy and intercanopy locations. Spatial autocorrelation in the residuals for soil moisture of up to $7 \mathrm{~m}$ was attributed to transpiration by woody plants at scales corresponding to belowground root distributions.

The spatial heterogeneities in near-ground solar radiation and soil moisture are of sufficient magnitude to affect biotic processes of woody and herbaceous plants, such as growth and seedling establishment. Because land degradation problems in semiarid shrublands and woodlands appear to result from differential impacts to intercanopy vs. canopy patches, our results can be used to help design effective mitigation and remediation strategies. More generally, our results demonstrate how the physical presence of woody canopies reinforces spatial heterogeneity in microclimate and, because our site has intermediate closure of the overstory, bridge the gap along a grassland-forest continuum between related studies in relatively open savannas and in forests with nearly closed canopies.

Key words: Bouteloua gracilis; canopy and intercanopy gaps; Juniperus monosperma; land degradation; microclimate; overstory; Pinus edulis; solar radiation and moisture; woodland.

\section{INTRODUCTION}

Degradation of semiarid ecosystems resulting from land use is a major environmental problem worldwide (Schlesinger et al. 1990, Ludwig and Tongway 1995). Changes in vegetation in these ecosystems can be sum-

Manuscript received 15 December 1995; revised 10 February 1997; accepted 12 March 1997. marized with respect to two plant functional typesherbaceous and woody. Both functional types provide important resources: herbaceous biomass provides forage for grazing, and woody biomass provides fuelwood. A reduction in the ratio of herbaceous to woody plant biomass is characteristic of many degraded semiarid ecosystems. Further, these changes are interrelated with increased erosion (Davenport et al. 1998), as well 
as with other ecosystem properties such as water infiltration capacity and nutrient cycling (Schlesinger et al. 1990, 1996). The sensitivity of these semiarid systems to land use is determined in part by their sensitivity to climate.

Semiarid ecosystems, shrublands and woodlands in particular, are highly sensitive to climate, as evident from biogeographical analyses (Stephenson 1990, Neilson et al. 1992). The proportions of the two plant functional types depend not only on the magnitude of climatic inputs, but also on intraannual timing and interannual variations (Eagleson and Segarra 1985, Neilson 1986, Neilson et al. 1992, Frank and Inouye 1994, Yeakley et al. 1994). The sensitivity of the two plant functional types to climatic differences has been explained in terms of differing abilities to exploit vertical heterogeneity in soil moisture, which is determined largely by climate (Walter 1971). The ratio of woody to herbaceous biomass in these systems is hypothesized to be related to the relative vertical distribution of shallow vs. deep soil moisture. Herbaceous plants are assumed to have predominant access to shallow soil moisture, whereas woody plants are presumed to have sole access to deeper water. Hence, the ratio of herbaceous to woody plant biomass is assumed to be a function of the ratio of shallow to deep soil moisture. Along the continuum from an open grassland with no overstory and a forest with complete closure of the overstory, the proportions of area comprised of canopy and intercanopy vary (Belsky and Canham 1994). The relative importance of solar radiation and soil moisture in determining ecosystem processes differs for the two ends of the grassland-forest continuum (Lauenroth et al. 1993); light is generally limiting in forests with nearly closed overstories, whereas soil moisture (as well as other belowground resources) is frequently limiting in ecosystems with relatively open overstories (e.g., grasslands and savannas). Disturbance processes such as fire and heavy grazing interact with climate to modify the canopy and intercanopy proportions.

Semiarid shrublands and woodlands, which are near the middle of the grassland-forest continuum, are composed of a large proportion of both canopy and intercanopy area, rather than being dominated by one or the other. Consequently, the overstory is highly heterogeneous and has intermediate closure. These ecosystems have a high degree of horizontal heterogeneity due to the presence or absence of canopy patches of woody plants. Woody canopies modify the microclimate and reinforce spatial heterogeneity via shading, interception of precipitation, and litterfall.

Recent models of water balance and vegetation dynamics have indicated that horizontal heterogeneity in microclimate between canopy and intercanopy patches influences ecosystem-scale processes (Sharpe et al. 1986, Walker et al. 1989, Mauchamp et al. 1994, Thiéry et al. 1995). Further, recent hypotheses about land degradation have focused on horizontal heterogeneity
(Grover and Musick 1990, Schlesinger et al. 1990): land impacts such as grazing and off-road vehicle use differentially impact canopy and intercanopy patches. Although horizontal heterogeneity between canopy and intercanopy patches has been well documented for nutrients (Charley and West 1975, Schlesinger et al. 1990, 1996, Padien and Lajtha 1992), direct field measurements of canopy and intercanopy heterogeneity in nearground solar radiation and soil moisture, two microclimatic factors of key importance for biological processes, are largely lacking in both degraded and nondegraded semiarid shrublands and woodlands.

Spatial variability in near-ground solar radiation has been studied primarily in forests with nearly complete closure of the overstory (Becker and Smith 1990, Canham et al. 1990, Rich et al. 1993a, Fournier et al. 1995, Clark et al. 1996). Reductions in near-ground solar radiation beneath woody canopies has been quantified relative to that in the "gaps" in the canopy (or intercanopy patches); further, sharp gradients have been found within intercanopy patches, gradients based on distance from the edge of the patch and on direction. This spatial heterogeneity varies temporally with solar position in predictable ways: east-west diurnal gradients and north-south seasonal gradients. However, similar studies in highly heterogeneous ecosystems with intermediate closure of the overstory are lacking.

The effects of overstory architecture on soil moisture heterogeneity are more complex because the physical effects of woody canopies on soil moisture are complicated by the biotic effects of the woody plants (i.e., water use) and redistribution of runoff. Canopies intercept precipitation (Sharpe et al. 1986, Joffre and Rambal 1988, 1993, Dawson 1993). Some of the intercepted precipitation may be concentrated around the trunk through stem flow (Martinez-Meza and Whitford 1996), some may be deposited at the edge through canopy drip (Collings 1966, Young and Evans 1987), and a substantial proportion can be lost via evaporation or sublimation (Young and Evans 1987). The effect of woody canopies on spatial variability in soil moisture for sites with very open overstories that contain a small proportion of isolated canopies is a reduction in soil moisture beneath these isolated canopies, as expected from measures of precipitation interception (Belsky et al. 1989). However, this effect can be offset by redistribution of runoff from intercanopy to canopy locations (Joffre and Rambal 1988, 1993, Cornet et al. 1992). Canopies reduce rainfall intensity, and the litter beneath them often has a greater infiltration capacity (Seyfried and Wilcox 1995); hence more runoff is generated in intercanopy patches (Wilcox 1994, Wilcox and Breshears 1995) and can be redeposited in canopy locations. Lacking are studies in highly heterogeneous ecosystems with intermediate cover that test for moisture gradients within the two patch types and that evaluate the effects of spatial heterogeneity in solar radiation on soil moisture. 
Our study was designed to test the hypothesis that the spatial pattern of the overstory imposes predictable spatial patterns in microclimatic variables, near-ground solar radiation and soil moisture, between and within canopy and intercanopy patch types. We studied a semiarid piñon-juniper woodland in northern New Mexico that had a highly heterogeneous overstory with intermediate cover $(\approx 50 \%$ canopy cover), and examined spatial patterns of the overstory, and the two microclimatic variables. The site was not degraded in that erosion rates were low and ground cover was moderate (Wilcox 1994). For near-ground solar radiation, we expected that in addition to canopy patches receiving less solar radiation than intercanopy patches, variation within patch type was different between centers and edges (canopy center < canopy edge; intercanopy center $>$ intercanopy edge) and between north and south edges (canopy north $<$ canopy south; intercanopy north $>$ intercanopy south). For soil moisture, we hypothesized that canopy patches would be drier than intercanopy patches due to the effect of interception, that edge locations would be wetter than center locations due to drip at canopy edges, and that within patches, edge locations that received less solar radiation would be wetter than edge locations that received more due to reduced evaporation. We also hypothesized that following intense storms, canopy locations would become wetter than intercanopy locations due to the redistribution of runoff from intercanopy to canopy patches. We expected the spatial pattern of near-ground solar radiation to be determined by the overstory pattern, whereas for soil moisture, we anticipated that other belowground processes and patterns could contribute to residual variation. Our results provide important information on how the canopies of woody plants reinforce spatial heterogeneity in microclimate. Further, measurements in nondegraded semiarid woodlands provide a baseline for comparison with other similar but degraded semiarid sites. Because land degradation problems in these environments appear to result from differential impacts to canopy or intercanopy locations, our results can be used to help design effective mitigatation and remediation strategies for addressing land degradation.

\section{Methods \\ Study site}

The Mesita del Buey study site is an upper-elevation $(2140 \mathrm{~m})$ piñon-juniper woodland in northern New Mexico, within Technical Area 51 of the Los Alamos Environmental Research Park (latitude $34.30^{\circ} \mathrm{N}$, longitude $106.27^{\circ} \mathrm{W}$ ). This site and nearby sites have been the subject of various long- and short-term ecological studies (Barnes 1986, Lajtha and Barnes 1991, Lin et al. 1992, Padien and Lajtha 1992, Breshears 1993, Lajtha and Getz 1993, Rich et al. 1993b, Wilcox 1994, Rich et al. 1995, Wilcox and Breshears 1995, Rich
1997). The area has a temperate montane climate, with annual precipitation of $\approx 40 \mathrm{~cm}$, mainly in the form of winter snowfall and late-summer precipitation (Bowen 1990). The soils are Hackroy sandy loam, derived from volcanic tuff (Nyhan et al. 1978); soil depth varies from 33 to $125 \mathrm{~cm}$ (Davenport et al. 1996). Allen (1989) describes the landscape ecology of this area, including historical land use and disturbances such as fire, drought, and insect infestations. The dominant overstory species are piñon pine (Pinus edulis Engelm.) and one-seed juniper (Juniperus monosperma [Engelm.] Sarg.). All piñons and junipers $>1 \mathrm{~m}$ in height were mapped and their crown characteristics recorded for a 4-ha area at the study site (Rich et al. 1993b, C. W. Meyer, D. D. Breshears, F. J. Barnes, and P. M. Rich, unpublished report). The density of $P$. edulis and $J$. monosperma is just over 500 woody individuals/ha, with near equal densities of the two species, an overstory canopy coverage of $50 \%$, and a clumped distribution of individual crowns (Padien and Lajtha 1992, Rich et al. 1993b). Ground cover in intercanopy areas adjacent to the study site is $\approx 85 \%$ with $\approx 50 \%$ from cryptogamic crust, $13 \%$ from grass (primarily Bouteloua gracilis (H.B.K.) Lag.), $2 \%$ semishrub, $1 \%$ forb, and $18 \%$ litter (Wilcox 1994); canopy areas are covered with litter and contain few herbaceous plants.

\section{Transect design}

A 102-m transect, running approximately southwest to northeast (bearing $213^{\circ} / 33^{\circ}$ ), is being used for longterm ecological studies at the Mesita del Buey study site. This transect was originally established in 1988; 11 access tubes were spaced along its length, $\approx 10 \mathrm{~m}$ apart, for measurement of soil moisture by means of neutron attenuation (Breshears 1993). In 1991, 103 sampling stations were added, at 1-m intervals, for measurement of soil moisture by time-domain reflectometry (TDR) and estimation of solar radiation from hemispherical photographs (Lin et al. 1992). We developed a general overstory index by categorizing each sampling station as "canopy" or "intercanopy" on the basis of whether or not woody overstory was present directly over the station. In addition, we recorded if there was an edge between the two patch types (canopy and intercanopy) within $1 \mathrm{~m}$ in each of the four cardinal directions. Edges to the north and south were mutually exclusive: the one location that was within $1 \mathrm{~m}$ of a canopy/intercanopy boundary to both the north and the south was categorized as the closer of the two (in this categorization, locations with an edge to either the north or south may also have an edge to the east and/or west). Thus, for analysis purposes, we were readily able to divide our sampling locations into eight categories. There were four types of canopy patches: canopy center, canopy north (canopy near an intercanopy to the north), canopy south (canopy near an intercanopy edge to the south), and canopy other (canopy near an intercanopy edge to the east and/or west but not to either 
the north or south). There were also four types of intercanopy patches: intercanopy center, intercanopy north (intercanopy near a canopy edge to the north), intercanopy south (intercanopy near a canopy edge to the south), and intercanopy other (intercanopy near a canopy edge to east and/or west but not to either the north or south).

\section{Measurements}

Solar radiation.-We characterized near-ground solar radiation levels for each sampling station using hemispherical photographs acquired during June and July of 1991 (Lin et al. 1992). Photographs were taken at heights of 1.0 and $1.75 \mathrm{~m}$ above the ground with Kodak TMAX 400 ASA film with a camera setting of 800 ASA, using a Nikon FM2 on a self-leveling mount and fitted with a Nikkor 8-mm fisheye lens that pointed directly upward. An identifying number was printed on each photograph by a Nikon MF16 databack. To ensure even skylight conditions, most photographs were taken just before sunrise (a few were taken just after sunset). Photographs were analyzed using the video imageanalysis system CANOPY (Rich 1989, 1990), which calculates the proportions of diffuse radiation (indirect site factor, or ISF) and direct radiation (direct site factor, or DSF) beneath the canopy relative to those above the canopy. Each photograph was analyzed twice and the values from the two analyses were averaged. Estimates from the two heights were similar (Lin et al. 1992). Three indices from photographs taken at the 1.0-m level were used for the current study: (1) diffuse solar radiation (ISF); (2) annual direct radiation (DSF); and (3) monthly direct radiation ( $\left.\mathrm{DSF}_{\text {month }}\right)$. These indices were calculated with a cosine correction relative to a horizontal plane. Further, for ISF, isotropic sky conditions (equal diffuse radiation from all sky directions) were assumed; for DSF, clear sky conditions were assumed, corrected for atmospheric attenuation as a function of zenith angle (Rich 1989, 1990). ISF can only be estimated annually. We estimated DSF annually and at monthly intervals, yielding 7 rather than 12 different time-dependent estimates within the year, because the sun angle is the same in months that precede and follow solstices by equal time periods (estimates were for December, January/November, February/October, March/September, April/August, May/July, and June).

Precipitation.-Precipitation was measured continuously at meteorological stations on study plots adjacent to the site (Nyhan et al. 1990). For snowfall, water equivalents on the surface were estimated by measuring snow depth at each of the sampling stations and estimating snow density from locations adjacent to the transect based on $5.6 \mathrm{~cm}$ diameter cores $(n=3$ canopy cores and $n=3$ intercanopy cores). Snow density was measured for most dates that depths were sampled (for dates when density was not measured, estimates from the closest date for which it was measured were used).
Soil moisture.- - Soil moisture was measured by timedomain reflectometry; (TDR; Topp et al. 1980, Topp and Davis 1985) using a system similar to that described by Baker and Allmaras (1990). The TDR probes, each $30 \mathrm{~cm}$ in length, were installed vertically in the soil at each of the transect sampling stations. A site-specific calibration factor for Hackroy sandy loam (J. W. Nyhan and T. G. Schofield, unpublished data) was applied to each estimate. Measurements were obtained at least every 5 wk over a nearly 4-yr period from July 1992 through May 1996, except during the 1992-1993 winter, when prolonged, deep snow cover precluded measurements.

\section{Analyses}

Temporal heteroscedasticity and spatial autocorrelation.-Our analyses were designed to account for both temporal and spatial variability in testing our hypotheses. In particular, we evaluated the data for two problems that could potentially complicate statistical analyses: spatial autocorrelation and temporal heteroscedasticity. The assumptions underlying the usual analysis of variance methods, where the coefficients of a linear model are estimated by ordinary least squares, are violated by both types of problems, because the residuals from ordinary least squares are assumed to be independently and identically distributed.

Initial evaluation of spatial autocorrelation was based on ISF and annual DSF data for solar radiation and a 4-yr, time-weighted average (obtained by linearly interpolating between measurement dates) for soil moisture. We calculated Moran's I (Sokal and Oden 1978, Sokal 1979, Fortin et al. 1989, Legendre and Fortin 1989, Legendre 1993) and tested for significance. As expected, the data were spatially autocorrelated at scales comparable to canopy and intercanopy patch sizes. In addition, however, spatial autocorrelation in the residuals from initial least squares analyses, a regression of solar radiation and soil moisture data on overstory indices, indicated that our hypothesis tests would need to account for some residual spatial autocorrelation.

We considered temporal variability at different scales for solar radiation and soil moisture. For solar radiation, we used the seven monthly intervals described above. For soil moisture, we estimated time-weighted averages over 6-mo periods spanning the winter/spring (December through May) and the summer/fall (June through November) of each year, yielding eight temporal categories (summer/fall 1992 through winter/ spring 1995-1996). We selected this temporal scale of resolution, which is larger than that used for solar radiation, because the sampling intervals for soil moisture measurements were irregular, but at least five measurements were obtained in each 6 -mo period. Temporal heteroscedasticity was evaluated based on variogram analysis of residuals from the initial least squares analyses with respect to the overstory indices. 
Variability was reasonably uniform among the seven temporal categories for solar radiation, although relatively minor differences among overstory classes were noted. However, large temporal variation, approximately proportional to the square of the average moisture in a given time period, was evident among the eight periods for soil moisture data. In particular, the winter/spring of 1992-1993 was extremely wet and the moisture data for this period exhibited very large variability both within and between overstory categories.

On the basis of these initial analyses, we developed two generalized least squares linear models, one for near-ground solar radiation and the other for soil moisture, incorporating covariance models that account for spatial autocorrelation and also, in the case of soil moisture, for temporal heteroscedasticity. (See Cressie 1991; Section 5.7.2, for discussion of this approach to the estimation of treatment effects in the presence of spatial autocorrelation.) Specifically, the underlying model for ordinary least squares analysis is normally distributed with mean $\boldsymbol{\chi} \boldsymbol{\beta}$ and variance $\sigma^{2} \mathbf{I}$, where for $p$ explanatory variables or categories, $\boldsymbol{\chi}$ is a design matrix of $N$ observations by $p$ variables, $\boldsymbol{\beta}$ is a vector of coefficients for $p$, $\mathbf{I}$ is the $N \times N$ identity matrix, and $\sigma^{2}$ is a scalar (the residual variance). To account for spatial autocorrelation and temporal heteroscedasticity in the residuals, a generalized least squares linear model replaces $\mathbf{I}$ by a $N \times N$ covariance matrix $\mathbf{W}$ (i.e., one that is symmetric and positive-definite). Nonzero off-diagonal terms of $\mathbf{W}$ correspond to spatial autocorrelation of the residuals, and on-diagonal terms will not all be equal to one if there is temporal heteroscedasticity (i.e., $\mathbf{W}$ need not be a correlation matrix). In the case of solar radiation, the diagonal terms are all equal to one, since temporal heteroscedasticity was judged to be minor, and only spatial autocorrelation was of concern. For soil moisture, where temporal heteroscedasticity was a problem, the diagonal terms for rows corresponding to measurements in the $i$-th time period are proportional to $1 / m(i)^{2}$, where $m(i)$ is the average moisture for the $i$-th time period. In both cases, the off-diagonal terms of $\mathbf{W}$ were estimated iteratively, together with the coefficients $\boldsymbol{\beta}$, from a semivariogram of the residuals.

Hypothesis tests. - We parameterized the model for near-ground solar radiation in terms of the following contrasts, added sequentially to test for significance of the hypothesized overstory effects: canopy locations receive less solar radiation than intercanopy locations; within patches, centers and edges differ (canopy center $<$ canopy edge; intercanopy center $>$ intercanopy edge), and there are expected north-south differences (canopy north < canopy south; intercanopy south < intercanopy north). At each step we also considered the significance of additional temporal variables (month and season $\times$ overstory interactions).

Similarly, for soil moisture, the model was parameterized to test the following hypotheses: canopy lo- cations are drier than intercanopy locations; edge locations are wetter than center locations; with a larger within-patch contrast in canopies. Further, within patch type, we expected north and south edges to differ (canopy south < canopy north; intercanopy south $>$ intercanopy north). Again, the significance of temporal variables and of season $\times$ overstory interactions was evaluated at each step. In addition, we tested for redistribution of runoff from intercanopy patches to canopy patches during summer storms by contrasting seasonal differences between intercanopy centers and canopy edges.

Supplemental calculations.-To evaluate the potential for spatial differences in solar radiation between canopy and intercanopy patches to influence soil moisture, we estimated potential evaporation as a function of solar radiation using the equations in Ritchie (1972). We used monthly maximum incoming solar radiation for White Rock (which has a long-term meteorological station near our study site; Bowen 1990) modified by $\mathrm{DSF}_{\text {month }}$ for canopy and for intercanopy locations. We assumed an albedo of 0.23 for canopy locations and of 0.11 for intercanopy locations. In addition, we used equations presented by Ritchie (1972) to calculate the potential soil evaporation rate, which is a function of soil texture. Since the predominant soil at our site is a Hackroy sandy loam, we assumed $60 \%$ sand and $15 \%$ clay in estimating the potential soil evaporation rate.

To better assess the biological importance of spatial heterogeneity in soil moisture, we converted soil moisture (volumetric water content) to soil water potential, using site-specific data (Breshears et al. 1997). Using mean values for spatial categories, we constructed a synthetic view of the local gradients of near-ground solar radiation and soil water potential as a function of spatial position for adjacent canopy and intercanopy patches. We used a single conversion for all categories because canopy and intercanopy locations do not differ in soil morphology at this site (Davenport et al. 1996).

\section{RESUlts}

\section{Spatial and temporal variability}

Fig. 1A shows the spacing of canopy and intercanopy locations along the transect as a band of black (canopy) and white (intercanopy) segments at the top of the figure. There were 54 intercanopy locations and 49 canopy locations, which comprised 10 intercanopy patches and 11 canopy patches. The intercanopy patch length was $5.4 \pm 4.0 \mathrm{~m}$ (mean $\pm 1 \mathrm{SD})$ and the mean canopy patch length was $4.5 \pm 2.7 \mathrm{~m}$. More than one-third of the locations $(n=38)$ were within $1 \mathrm{~m}$ of a canopy/intercanopy edge to the north and/or south. An additional 13 locations were within an edge to either the east and/or west but not to the north or south. As shown in Fig. 1A, the variations in both the solar radiation indices, ISF and DSF, indicate a strong relationship with the canopy/intercanopy index for the overstory (Fig. 

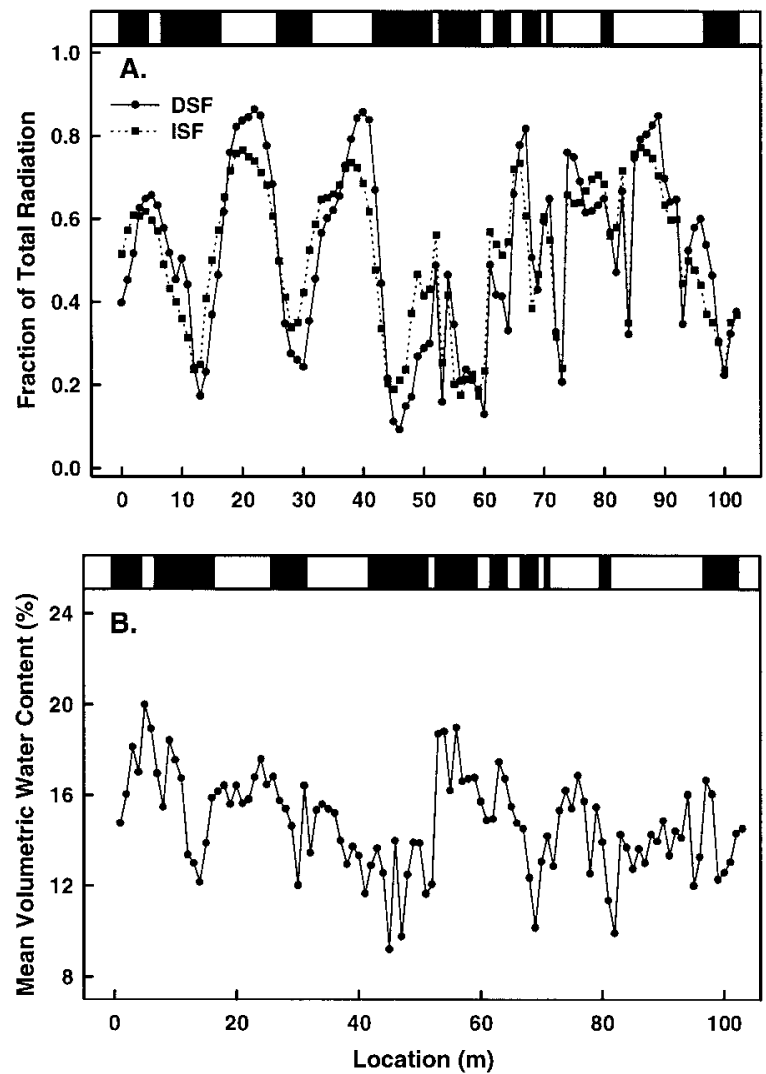

FIG. 1. The overstory index along the transect is represented by the bar at the top of each part of the figure (black = canopy, white = intercanopy). (A) Direct (DSF) and indirect (ISF) site factors for the fraction of total solar radiation at each location; DSF is the annual estimate. (B) Mean volumetric water content (\%), based on 4-yr data set from each location.

1A). Similarly, the variations in mean soil moisture along the transect also varied in a pattern similar to that of the canopy/intercanopy variations (Fig. 1B; the overstory pattern is repeated again in Fig. 1B for reference).

The spatial heterogeneity in solar radiation and soil moisture imposed by the overstory was modified temporally. The amount of temporal variability in solar radiation was related to spatial position (Fig. 2A): the amount of incoming solar radiation for intercanopy patches (corresponding to locations with a high DSF) varied more temporally than that for canopy patches. The mean temporal variability for canopy and intercanopy locations can be summarized as follows (Fig. 2B): temporal changes were greatest between February and March and between August and September; direct solar radiation varied much less temporally within canopy than within intercanopy locations; and the difference between canopy and intercanopy locations was greatest during the summer solstice and least during the winter solstice. The differences between canopy and intercanopy locations were amplified when the di-
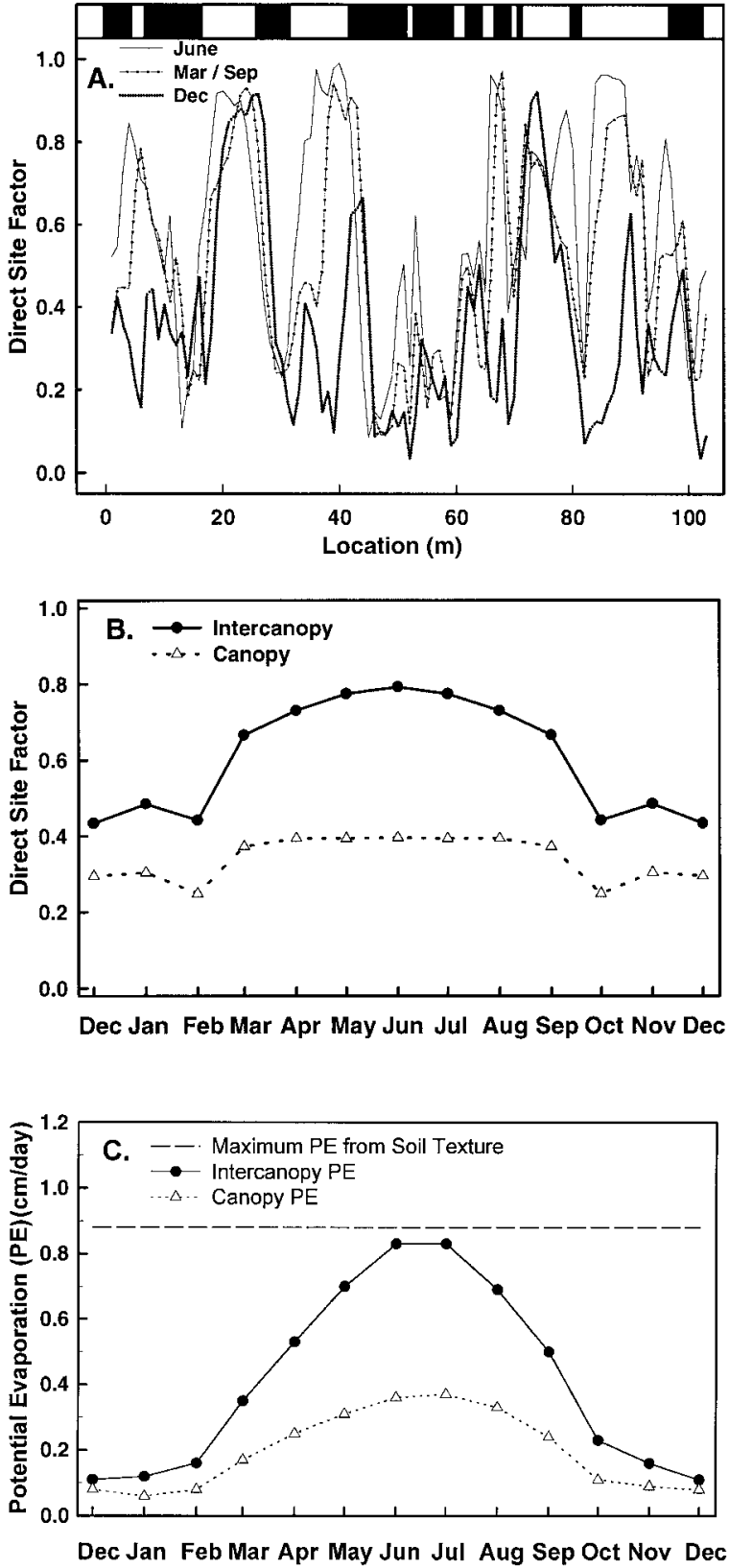

FIG. 2. (A) The overstory index along the transect is represented by the bar at the top of the figure. The direct site factor (DSF) for monthly intervals for each location is shown for December, March/September (the estimate is the same for these two months), and June. (B) The direct site factor (DSF) for intercanopy and canopy locations for each month. (C) Potential soil evaporation (PE; centimeters per day) as estimated from Ritchie (1972) for incoming radiation and the threshold for the maximum soil evaporation rate, as limited by soil texture.

rect site factor was used to calculate the potential soil evaporation for monthly maximum solar radiation (Fig. 2C). These rates did not exceed the upper limit for the evaporation rate of bare soil $(0.88 \mathrm{~cm} / \mathrm{d})$, as limited by soil texture (Ritchie 1972; Fig. 2C). 

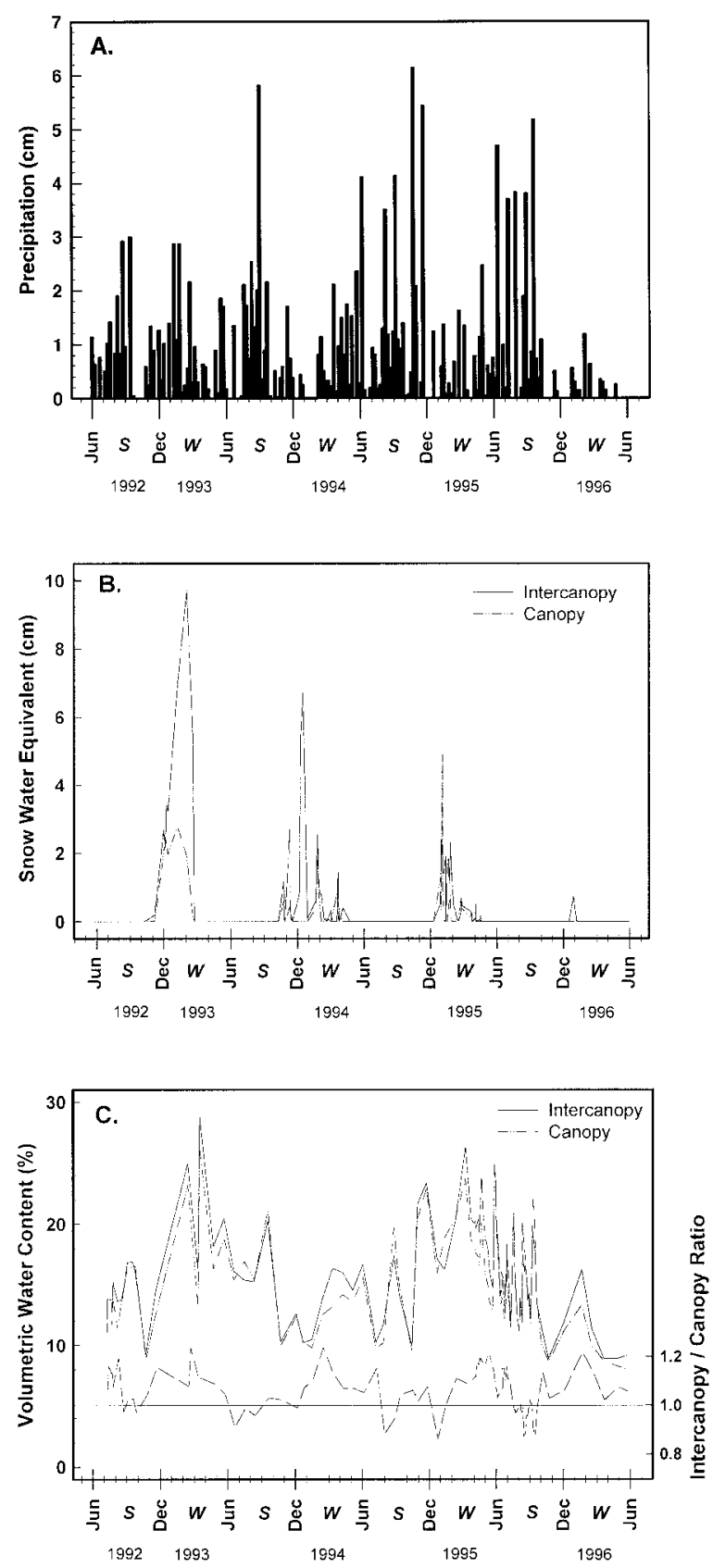

FIG. 3. Time-series measurements for (A) precipitation, (B) snow water equivalent in intercanopy and canopy locations, and (C) volumetric water content (\%) for intercanopy and canopy locations, and the ratio of intercanopy to canopy mean volumetric water content. $S=$ summer/fall; $W=$ winter/ spring.

The majority of the precipitation during the study period occurred as snow over the winter and as rain during the late summer monsoon season (Fig. 3A). Snow cover was greater and more persistent in intercanopy locations than canopy locations (Fig. 3B). Although intercanopy locations were wetter than canopy locations when averaged across time, the magnitude

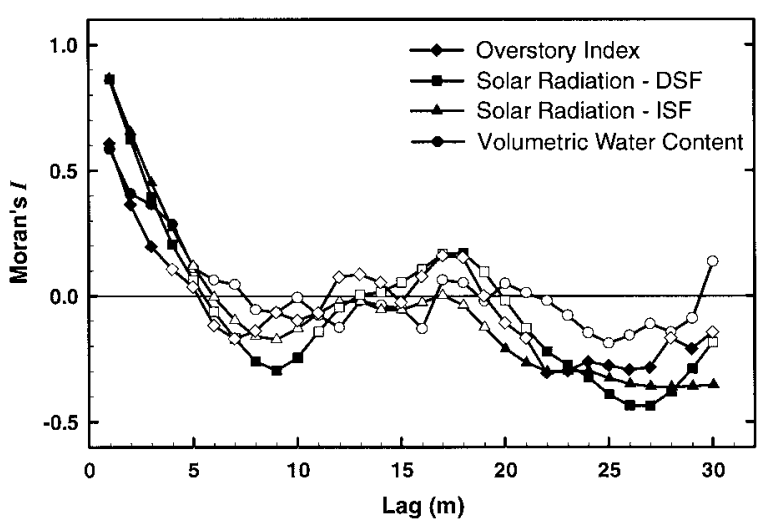

FIG. 4. Spatial autocorrelation, as measured by Moran's $I$ vs. lag, for overstory index, annual direct site factor (DSF), annual indirect site factor (ISF), and mean volumetric water content. Solid symbols denote $P<0.05$.

and direction of canopy/intercanopy differences was time dependent (Fig. 3C). Following snow melt, intercanopy locations were wetter than canopy locations by as much as $3 \%$ volumetric water content (Fig. 3C), but the magnitude of the differences diminished as soils dried. Canopy locations became wetter than intercanopy locations following periods of intense rainstorms that generated runoff, which occurred during late summer and early fall of each year (Wilcox 1994; B. P. Wilcox, unpublished data). (In addition, canopy locations were wetter than intercanopy locations in January 1995 when snow had melted in canopy locations but had not yet melted in intercanopy locations; intercanopy locations later became wetter than canopy locations following snowmelt.)

\section{Spatial autocorrelation}

Spatial autocorrelation was evident in the overstory index, solar radiation indices (ISF and DSF), and mean soil moisture (Fig. 4). The correlograms showed positive correlation for all four variables at lag distances of $5 \mathrm{~m}$ or less, with statistically significant lags $(P<$ 0.05 ) at $1-3 \mathrm{~m}$ for the overstory and $1-4 \mathrm{~m}$ for solar radiation and soil moisture variables. The correlograms for all four variables were also similar for longer lags. The overstory index and both solar radiation indices had significant negative correlation at some lags $>20$ $\mathrm{m}$.

The spatial autocorrelation in the overstory index accounts for only part of the spatial autocorrelation in both the solar radiation and soil moisture data. Residuals from ordinary least squares models in which these data are regressed on the overstory index are still autocorrelated. This led to the use of generalized least squares models, as described previously. Residuals from the final optimized model, including temporal and interaction terms, are still autocorrelated for solar radiation (DSF) at lags out to $3 \mathrm{~m}$ (Fig. 5A) and for soil moisture at lags out to $7 \mathrm{~m}$ (Fig. 5B). In addition, the residuals for soil moisture have a substantial uncor- 

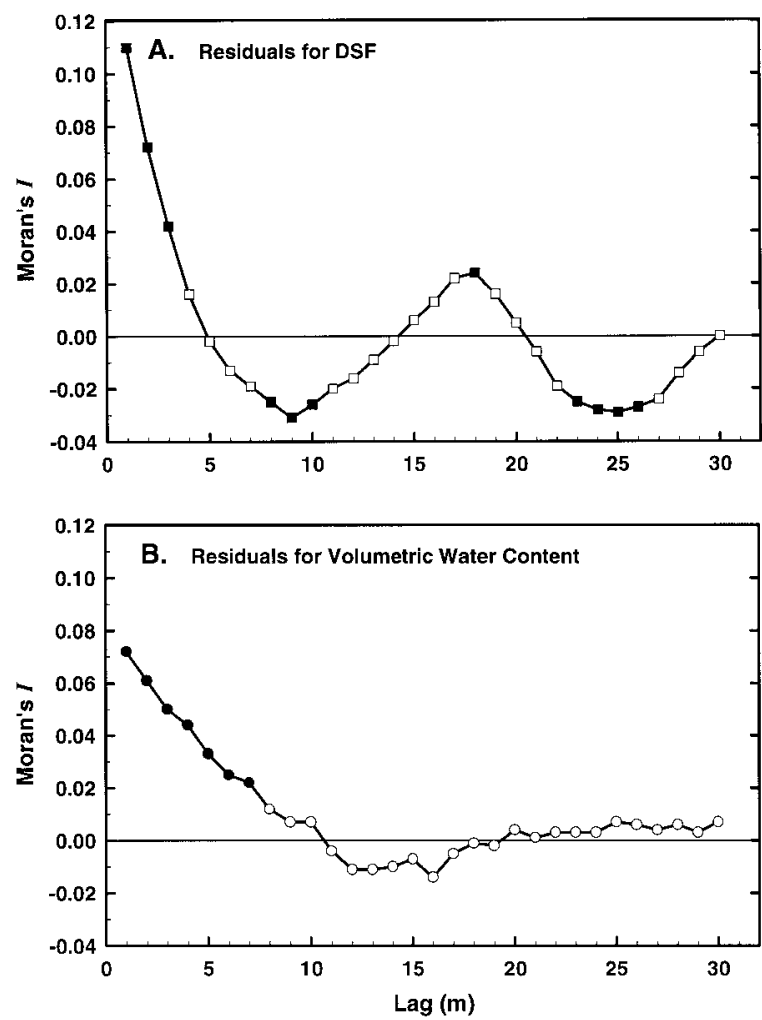

FIG. 5. (A) Spatial autocorrelation (Moran's $I$ ) in residuals from generalized least squares models for (A) solar radiation (direct site factor, DSF) and (B) soil moisture (\% volumetric water content). Solid symbols denote $P<0.05$.

related component $(\approx 30 \%$ of the total residual variance); there is no uncorrelated component in the residuals from the solar radiation model.

\section{Hypothesis tests}

Results for tests of hypotheses about near-ground solar radiation are presented in Table 1. Both the spatial and temporal variables significantly increase predictive capability at each step. We found most of the expected spatial variation. Between patches, canopy $<$ intercanopy $(P<0.001)$, and this effect is significantly stronger in summer/fall $(P<0.001)$. Within patches, centers differed significantly from edges $(P<0.001)$, and the direction of the difference was opposite between the two patch types, as expected (canopy center $<$ canopy edge: $P<0.001$; intercanopy center $>$ intercanopy edge: $P<0.01$ ); for canopies, this variation was more pronounced in summer/fall than winter/spring $(P=$ $0.02)$. Within patches, there were also differences between north and south edges $(P<0.001)$ with the direction of the difference again varying between patch type (canopy north $<$ canopy south: $P<0.001$; intercanopy north $>$ intercanopy south: $P<0.001$ ); these differences were not significant in summer/fall $(P>$ 0.09).

Of course, the temporal variability for our near- ground solar radiation estimates has been induced deterministically (rather than actually measured) by the CANOPY program in calculating monthly solar radiation from photographs. The interesting result from the regression analysis is that the full monthly model is not better $(P=0.09)$ than a model including only a simple two-season contrast between near summer solstice (April through August) and near winter solstice (October through February).

Results for tests of hypotheses about soil moisture are presented in Table 2. Both spatial and temporal variables increased predictive capability, but the interaction terms between overstory as a spatial variable and a seasonal contrast between summer/fall and winter/spring were not significant, for the most part.

Canopy locations were significantly drier than intercanopy locations $(P<0.001)$, and the difference was about the same summer and winter $(P \approx 1.0)$. Within patch types, edge locations were significantly wetter than center locations $(P<0.001)$. This effect was somewhat stronger in summer, but not significantly $(P=0.13)$, and was also significantly greater in canopy patches $(P<0.001)$.

Overall, soil moisture for north edges was not significantly different from that for south edges $(P=$ 0.09). Within the intercanopy, south edges (which receive less solar radiation than north edges) were significantly different from north edges $(P<0.05)$. However, this effect was in the opposite direction than expected (edges receiving less solar radiation were drier) and occurred only during the winter.

We tested for redistribution of runoff from intercanopy patches to canopy patches by contrasting seasonal difference between intercanopy center locations and canopy edges (an alternative parameterization of the level 2 models in Table 2). The soil moisture difference between the two patches changed in the expected direction (intercanopy center $<$ canopy edges) from winter/spring to summer/fall, but the difference was not significant $(P=0.23)$.

Results from the generalized least squares models for soil moisture were converted to soil water potential and are presented in conjunction with those for solar radiation (Fig. 6). In canopy patches, solar radiation is reduced by more than half and soil water potential is $40 \%$ less than in canopy patches. Further, within-patch gradients, as tested above, are apparent.

\section{DISCUSSION}

\section{Overstory-imposed heterogeneity in solar radiation and soil moisture}

Our results supported our general concept that the spatial pattern of the overstory defines predictable solar radiation and soil moisture patterns, effectively creating a variety of microclimatic zones (Fig. 6, Tables 1 and 2). Overstory geometry imposes predictable spatial and temporal variation in near-ground solar radi- 
TABLE 1. Spatial and temporal (T) variability for near-ground solar radiation (S), as tested using a generalized least squares model.

\begin{tabular}{|c|c|c|c|c|c|}
\hline \multirow[b]{2}{*}{ Spatial variables } & \multicolumn{3}{|c|}{ Temporal variables } & \multirow[b]{2}{*}{$\begin{array}{l}\text { Overstory } \\
\text { contrasts }\end{array}$} & \multirow[b]{2}{*}{$\begin{array}{c}\text { Temporal } \\
\text { interactions } \\
\text { with overstory } \\
\text { contrasts }\end{array}$} \\
\hline & $\begin{array}{l}\text { None } \\
\text { (S) }\end{array}$ & $\begin{array}{l}\text { Month } \\
\text { (ST) }\end{array}$ & $\begin{array}{l}\text { Month }+ \\
\text { solstice } \times \\
\text { overstory } \\
\quad(\text { IST) }\end{array}$ & & \\
\hline 0) None & S0 & $\begin{array}{c}\text { ST0: } r^{2}=3.6 \% \\
P(\mathrm{~S} 0)<0.01\end{array}$ & & & \\
\hline $\begin{array}{l}\text { 1) Canopy vs. } \\
\text { intercanopy }\end{array}$ & $\begin{array}{l}\mathrm{S} 1: r^{2}=11.8 \% \\
\quad P(\mathrm{~S} 0)<0.0001\end{array}$ & $\begin{array}{l}\text { ST1: } r^{2}=15.5 \% \\
\quad P(\mathrm{ST} 0)<0.0001 \\
\quad P(\mathrm{~S} 1)<0.0001\end{array}$ & $\begin{array}{l}\text { IST1: } r^{2}=20.4 \% \\
\quad P(\text { ST1 })<0.0001\end{array}$ & $\begin{array}{l}\text { canopy }<\text { inter- } \\
\text { canopy } \\
(P<0.001)\end{array}$ & $\begin{array}{l}\text { more pronounced } \\
\text { in summer/fall } \\
\text { than winter/ } \\
\text { spring } \\
(P<0.001)\end{array}$ \\
\hline $\begin{array}{l}\text { 2) Row } 1+ \\
\text { within patches: } \\
\text { center vs. edg- } \\
\text { es }\end{array}$ & $\begin{array}{l}\mathrm{S} 2: r^{2}=20.2 \% \\
\quad P(\mathrm{~S} 1)<0.0001\end{array}$ & $\begin{array}{l}\text { ST2: } r^{2}=23.9 \% \\
\quad P(\mathrm{ST} 1)<0.0001 \\
\quad P(\mathrm{~S} 2)<0.0001\end{array}$ & $\begin{array}{l}\text { IST } 2: r^{2}=29.4 \% \\
\quad P(\text { IST } 1)<0.0001 \\
P(\text { ST2 })<0.0001\end{array}$ & $\begin{array}{l}\text { canopy center }< \\
\text { canopy edge } \\
\quad(P<0.001) \\
\\
\text { intercanopy center } \\
\quad>\text { intercanopy } \\
\text { edge } \\
\quad(P<0.01)\end{array}$ & $\begin{array}{l}\text { more pronounced } \\
\text { in summer/fall } \\
\text { than winter/ } \\
\text { spring } \\
(P=0.02) \\
\text { no different in } \\
\text { summer/fall } \\
\text { than winter/ } \\
\text { spring } \\
(P=0.44)\end{array}$ \\
\hline $\begin{array}{l}\text { 3) Row } 2+ \\
\text { within patches: } \\
\text { north vs. south } \\
\text { edges }\end{array}$ & $\begin{array}{l}\mathrm{S} 3: r^{2}=23.8 \% \\
\quad P(\mathrm{~S} 2)<0.0001\end{array}$ & $\begin{array}{l}\text { ST3: } r^{2}=27.4 \% \\
\quad P(\mathrm{ST} 2)<0.0001 \\
\quad P(\mathrm{~S} 3)<0.0001\end{array}$ & $\begin{array}{l}\text { IST } 3: r^{2}=34.4 \% \\
P(\text { IST2 })<0.0001 \\
P(\text { ST3 })<0.0001\end{array}$ & $\begin{array}{l}\text { canopy north }< \\
\text { canopy south } \\
(P<0.001) \\
\text { intercanopy north } \\
\quad>\text { intercanopy } \\
\text { south } \\
\quad(P=0.001)\end{array}$ & $\begin{array}{l}\text { not significant in } \\
\text { summer/fall } \\
(P=0.094) \\
\text { not significant in } \\
\text { summer/fall } \\
(P=0.096)\end{array}$ \\
\hline
\end{tabular}

Note: Spatial variables related to overstory are added down rows (0 through 3), temporal variables across columns (S for no consideration of temporal differences, ST for inclusion of temporal variables for monthly periods, and IST for interaction between spatial variables and temporal variables). Significant improvements in prediction are made moving down rows and across columns, as indicated by $P($ model) values in each cell under temporal variables. Overstory contrasts for each level of spatial variable and temporal interactions with overstory contrasts are listed to the right.

ation. Our results extend the findings of other studies of near-ground solar radiation in relatively homogeneous canopies to highly heterogeneous canopies. More specifically, our results quantify the expected reductions in solar radiation in canopy patches due to shading, and they support expected gradients within both patch types. At our site with intermediate closure of the overstory, the canopy is a series of alternating canopy and intercanopy patches (Fig. 4). The center portions of canopy patches receive $40 \%$ less nearground solar radiation than intercanopies on average (Fig. 6), and $>50 \%$ less during much of the growing season (Fig. 2B). The shading effects of the canopies are quantified in that edge locations within a patch type received less solar radiation than center locations (Fig. 6). Further, these shading effects produce contrasting north and south patterns within patches (canopy north $<$ canopy south; intercanopy north $>$ intercanopy south). Our statistical analysis of solar radiation based on the eight cover types was not sufficiently robust to remove all of the spatial autocorrelation in the data: the residuals were spatially autocorrelated at a scale of $3 \mathrm{~m}$ (Fig. 5A), the same scale as the spatial autocorrelation for the canopy/intercanopy pattern (Fig. 4). The eight cover categories fail to account for many attributes of canopy architecture associated with our measurements, including tree heights, patch size, tree locations, and foliar density. Hence, the remaining spatial autocorrelation in the residuals can be attributed to additional shading effects of the canopy on the alternating canopy/intercanopy areas that are not determined by our categories. Temporally, near-ground solar radiation is more variable within intercanopy locations than canopy locations. Our results are consistent with those from studies of environments with nearly complete closure of the overstory (Becker and Smith 1990, Canham et al. 1990, Rich et al. 1993a, Clark et al. 1995, Fournier et al. 1995) and link them to a broader range of overstories along the grassland-forest continuum.

Overstory geometry also influences soil moisture patterns. Our results extend those of soil moisture in more open canopies to highly heterogeneous canopies by addressing within-patch heterogeneity as well as between-patch heterogeneity. In addition, we evaluated potential effects of spatial heterogeneity in near-ground solar radiation on soil moisture. The effect of the canopy patches on soil moisture heterogeneity is evident in the spatial autocorrelation at a scale similar to that of the overstory (Fig. 4) and in the hypothesis tests 
TABLE 2. Spatial and temporal (T) variability for soil moisture (M), as tested using a generalized least squares model.

\begin{tabular}{|c|c|c|c|c|c|c|}
\hline \multirow{2}{*}{\multicolumn{2}{|c|}{ Spatial variables }} & \multicolumn{3}{|c|}{ Temporal variables } & \multirow[b]{2}{*}{$\begin{array}{l}\text { Overstory } \\
\text { contrasts }\end{array}$} & \multirow[b]{2}{*}{$\begin{array}{c}\text { Temporal } \\
\text { interactions } \\
\text { with overstory } \\
\text { contrasts } \\
\end{array}$} \\
\hline & & $\begin{array}{l}\text { None } \\
(\mathrm{M})\end{array}$ & $\begin{array}{l}\text { Year/season } \\
(\mathrm{MT})\end{array}$ & $\begin{array}{c}\text { Year/season }+ \\
\text { season } \times \text { overstory } \\
(\text { IMT) }\end{array}$ & & \\
\hline 0) & None & M0 & $\begin{array}{l}\text { MT0: } r^{2}=19 \% \\
P(\mathrm{M} 0)<0.0001\end{array}$ & & & \\
\hline 1) & $\begin{array}{l}\text { Canopy vs. } \\
\text { intercanopy }\end{array}$ & $\begin{array}{l}\text { M1: } r^{2}=11.6 \% \\
\quad P(\mathrm{M} 0)<0.0001\end{array}$ & $\begin{array}{c}\text { MT1: } r^{2}=25.5 \% \\
P(\mathrm{MT0})<0.0001 \\
P(\mathrm{M} 1)<0.0001\end{array}$ & $\begin{array}{l}\text { IMT1: } r^{2}=25.5 \% \\
P(\text { MT } 1)=0.97\end{array}$ & $\begin{array}{l}\text { canopy }<\text { inter- } \\
\text { canopy } \\
\quad(P<0.001)\end{array}$ & $\begin{array}{l}\text { summer/fall same } \\
\quad \text { as winter/spring } \\
\quad(P \approx 1.0)\end{array}$ \\
\hline 2) & $\begin{array}{l}\text { Row } 1+\text { cen- } \\
\text { ter vs. edges }\end{array}$ & $\begin{array}{l}\text { M2: } r^{2}=19.2 \% \\
\quad P(\mathrm{M} 1)<0.0001\end{array}$ & $\begin{array}{c}\text { MT2: } r^{2}=33.1 \% \\
P(\mathrm{MT} 1)<0.0001 \\
P(\mathrm{M} 2)<0.0001\end{array}$ & $\begin{array}{r}\text { IMT2: } r^{2}=33.2 \% \\
P(\text { MT2 })=0.14\end{array}$ & $\begin{array}{c}\text { centers }<\text { edges } \\
(P<0.001)\end{array}$ & $\begin{array}{l}\text { summer/fall same } \\
\text { as winter/spring } \\
(P=0.13)\end{array}$ \\
\hline 3) & $\begin{array}{l}\text { Row } 2+\text { in- } \\
\text { teraction }\end{array}$ & $\begin{aligned} & \text { M3: } r^{2}=19.9 \% \\
& P(\mathrm{M} 2)<0.01\end{aligned}$ & $\begin{array}{c}\text { MT3: } r^{2}=33.8 \% \\
P(\text { MT2 })<0.01 \\
P(\text { M3 })<0.0001\end{array}$ & $\begin{array}{l}\text { IMT3: } r^{2}=34.2 \% \\
\quad P(\text { MT3 })=0.32\end{array}$ & $\begin{array}{l}\text { within canopy ef- } \\
\text { fect }>\text { within } \\
\text { intercanopy ef- } \\
\text { fect } \\
\quad(P<0.001)\end{array}$ & $\begin{array}{l}\text { summer/fall same } \\
\text { as winter/spring } \\
(P=0.32)\end{array}$ \\
\hline 4) & $\begin{array}{l}\text { Row } 3+\text { with- } \\
\text { in patches: } \\
\text { north vs. } \\
\text { south edges }\end{array}$ & $\begin{array}{l}\text { M4: } r^{2}=20.3 \% \\
P(\mathrm{M} 3)=0.14\end{array}$ & $\begin{array}{l}\text { MT4: } r^{2}=34.2 \% \\
P(\text { MT3 })=0.094 \\
P(\text { M4 })<0.0001\end{array}$ & $\begin{array}{l}\text { IMT4: } r^{2}=34.6 \% \\
\quad P(\text { MT4 })<0.05\end{array}$ & $\begin{array}{l}\text { canopy north vs. } \\
\text { canopy south: } \\
\text { no difference } \\
(P=0.56) \\
\text { intercanopy north } \\
>\text { intercanopy } \\
\text { south } \\
(P<0.05)\end{array}$ & $\begin{array}{l}\text { not significant } \\
\quad(P=0.37) \\
\text { not significant in } \\
\quad \text { summer/fall } \\
\quad(P=0.90)\end{array}$ \\
\hline
\end{tabular}

Note: Spatial variables related to overstory are added down rows (0 through 4$)$, temporal variables across columns (M for no consideration of temporal differences, MT for inclusion of temporal variables for monthly periods, and IMT for interaction between spatial variables and temporal variables). Significant improvements in prediction are made moving down rows and from M to MT models (and from MT4 to IMT4), as indicated by $P$ (model) values in each cell under temporal variables. Overstory contrasts and temporal interactions with overstory contrasts for each level of spatial variable are listed to the right.

(Table 2) and predictions of the generalized least squares models (Fig. 6). Further, within-patch heterogeneity was as important as between-patch variability in explaining variance in soil moisture (Table 2). In our site with a highly heterogeneous overstory, a much greater proportion of the area is near an edge between canopy and intercanopy patches in comparison to sites with more open overstory. Hence, we find that withinpatch heterogeneity is important in this site with intermediate cover $(\approx 50 \%)$.

We tested hypotheses about the effects of canopy

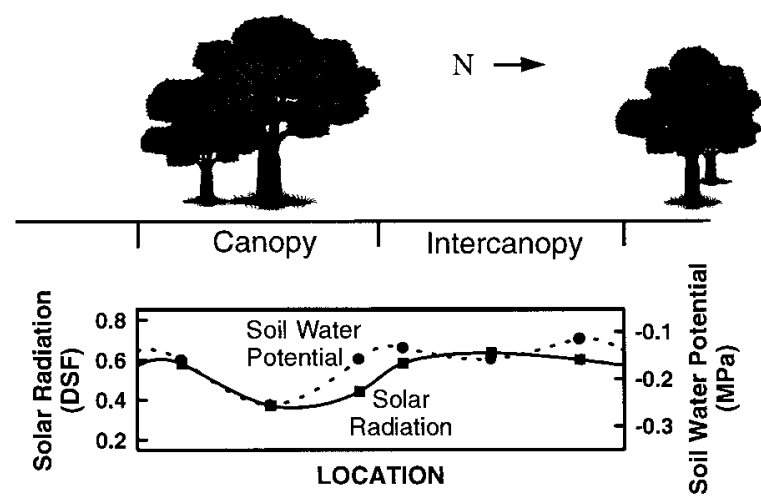

FIG. 6. Mean values for gradients in solar radiation and soil water potential along a north-south transect through a canopy and an intercanopy patch, estimated from generalized least squares models. patches on spatial heterogeneity in soil moisture that may be attributable to a combination of three physical effects-interception and drip, soil evaporation as modified by near-ground solar radiation, and redistribution of runoff from intercanopy to canopy patchesand/or biological effects (i.e., plant water use). Our results suggest that the primary process determining differences between canopy and intercanopy locations is interception and drip, the first physical effect of the tree canopy. The spatial autocorrelation of time-averaged soil moisture is similar to that for the overstory (Fig. 4), which shows positive correlation at intervals of $\approx 5 \mathrm{~m}$-approximately the average length of the canopy and the intercanopy patches on the transect. We are also able to detect the effects of canopy drip associated with interception: within both patch types, edge locations are significantly wetter than center locations (Table 2, Fig. 6). The measurements of snowwater equivalent show large differences between canopy and intercanopy locations every winter, even for the dry winter of 1995-1996 (Fig. 3B). The interception of precipitation by woody canopies and the underlying litter has been shown to be significant at other semiarid sites (Johnsen 1962, Skau 1964, Collings 1966, Young and Evans 1987, Belsky et al. 1989), resulting in reduced soil moisture beneath canopies.

Our results show some evidence of the second physical effect of woody canopies, near-ground solar radiation on soil moisture, although the effects are small. 
The only effect of solar radiation on soil moisture that we were able to detect was that within intercanopies, the north edges, which received more solar radiation than the south edges, were wetter than the south edges in the winter/spring. This is likely due to increased canopy drip effects on the warmer sides of tree canopies, as has been observed previously (Collings 1966). Spatial heterogeneity in solar radiation is expected to modify soil moisture based on differences in potential evaporation between canopy and intercanopy patches (Fig. 2C). Our soil moisture measurements included the main depth interval for which soil evaporation occurs (Newman et al. 1997). We did not account for actual temporal differences in cloudiness over the 4-yr period, which may have reduced our ability to detect effects of solar radiation on soil moisture. However, such effects were generally overwhelmed by the effects of interception and canopy drip.

Our data also suggest that the third physical effect, redistribution of runoff from intercanopy to canopy patches, may be operating: the ratio of intercanopy-tocanopy soil moisture drops to $<1$ each year in the summer following runoff-generating storms (Fig. 3C). While the contrast between intercanopy centers and canopy edges shifted in the expected direction in summer, as did the contrast between canopy center and canopy edge (as would be expected if intercanopy runoff was being redistributed to canopy edges), neither of these shifts was statistically significant in our analyses. Seasonal differences in the effect of canopy drip could also cause these differences. Another analysis that had less temporal averaging might be able to detect redistribution of runoff to canopy patches. Although our results suggest that runoff may be being redistributed to canopy patches, overall this process is less important than interception in determining soil moisture heterogeneity at our site. Redistribution of runoff to canopy patches has been shown at other sites (Joffre and Rambal 1988, 1993, Cornet et al. 1992, Seyfried and Wilcox 1995), which may have greater differences in infiltration capacity and microtopography between canopy and intercanopy patches; at our site, soil morphological properties do not differ significantly between canopy and intercanopy patches except for the presence of litter in the canopy patches (Davenport et al. 1996). The contrast between our site and these others highlights the important interplay between herbaceous plant cover in intercanopy locations, soil infiltration differences between canopy and intercanopy patches, and redistribution of runoff from intercanopy patterns to canopy patches.

The spatial heterogeneity in soil moisture that we observed could be due to differences in plant water uptake between the canopy and intercanopy locations. Greater rooting density beneath the canopy patches (presumably by woody plants) may be related to greater water use in canopy patches, further increasing the spatial heterogeneity resulting from reduced precipitation inputs (Fig. 3B); organic C is nearly five times greater in canopy than intercanopy soils at this site (Davenport et al. 1996). However, the spatial heterogeneity between patch types is greatest after snow melts, and the rates of soil moisture depletion (Fig. 3B, C) between canopy and intercanopy patches do not appear to differ greatly (Fig. 3C). This suggests that the spatial heterogeneity in soil moisture between canopy and intercanopy patches is primarily due to interception rather than to differences in plant water uptake. Nonetheless, our results do indicate that plant water use is affecting soil moisture heterogeneity. Water uptake by woody plants is not limited to the same spatial scale as the aboveground pattern of the canopy patches. Both $P$. edulis and J. monosperma can use shallow intercanopy soil moisture, as demonstrated in a manipulative experiment at this site (Breshears et al. 1997). Tracer experiments indicated trees up to $8 \mathrm{~m}$ away from wet intercanopy patches could obtain detectable amounts of the labeled water (Breshears 1993). In this study the residuals from the generalized least squares model are spatially autocorrelated at scales of up to $7 \mathrm{~m}$ (Fig. 5B), well beyond the scale of the aboveground canopy patches (Fig. 4; Martens et al. 1997). Hence, we attribute this spatial autocorrelation to the belowground neighborhood of patches of woody plants.

Our results clearly demonstrate that there is important spatial heterogeneity in solar radiation and soil moisture between canopy and intercanopy patches and there are predictable gradients within each patch type. For solar radiation, these within-patch gradients are north to south due to solar angle, whereas for soil moisture, the within-patch differences are between edges and center locations, with edges being wetter due to canopy drip. These results vary somewhat temporally between seasons. For both solar radiation and soil moisture, $>30 \%$ of the variance is explained, despite the coarse temporal resolution of our analyses (Tables 1 and 2). We expect that additional variance can be explained for solar radiation by accounting for canopy architecture and for soil moisture by collecting and evaluating data on a finer temporal scale. Our results help link studies of overstory effects along the grassland-forest continuum to one another and indicate how canopy architecture amplifies spatial variability in solar radiation and soil moisture: two key microclimatic variables that affect several important plant processes for both herbaceous and woody plants.

\section{Relevance of overstory-imposed heterogeneity for environmental problems}

We studied spatial heterogeneity in soil moisture and solar radiation in a nondegraded semiarid woodland. Our results provide a baseline set of measures quantifying how woody canopy patches of the overstory reinforce spatial heterogeneity in a nondegraded semiarid ecosystem. These results can be used to help un- 
derstand ecosystem processes in nondegraded and degraded semiarid ecosystems.

The spatial and temporal variability in the two patch types, canopy and intercanopy, is of sufficient magnitude to influence many important plant processes for both herbaceous and woody plants. In comparison to the centers of intercanopy patches, the centers of canopy patches are reduced on average by $>60 \%$ for soil water potential and $>40 \%$ for near-ground solar radiation (Fig. 6). Further, there is substantial variation within each patch (Fig. 6). The relationship between soil moisture (volumetric water content) and soil water potential is nonlinear, such that as soil moisture dries, soil water potential changes only slightly at first and then dramatically. For our soils, this transition occurs slightly below $15 \%$ volumetric water content. Hence, the observed differences between canopy and intercanopy of 1-3\% volumetric water content (Fig. 3C) may not be biologically important when both patch types are wet $(>15 \%)$, but as soils dry, these small spatial differences become amplified in terms of soil water potential, leaf water potential, and conductance for predominant species of both herbaceous (B. gracilis; Sala et al. 1981) and woody ( $P$. edulis and J. monosperma; Barnes 1986, Lajtha and Barnes 1991, Breshears 1993) plant types at our site. Small differences in the length of time during which the soil has adequate moisture for plant growth appear to amplify the probabilities of successful establishment for B. gracilis (Aguilera and Lauenroth 1995); the same is likely for $P$. edulis and $J$. monosperma at our site, and other herbaceous and woody species at other sites.

The spatial differences in near-ground solar radiation influence not only light, but also soil and leaf temperatures. Canopy and intercanopy patches differ in soil temperature (Emerson 1932, Johnsen 1962, Everett and Sharrow 1985, Pierson and Wight 1991), which affects germination of $P$. edulis (Kintigh 1949). Effects of soil temperature on herbaceous establishment are less clear (Everett and Sharrow 1985; Aguilera and Lauenroth 1995). In addition, transpiration rates of both $P$. edulis and $J$. monosperma are sensitive to leaf temperature (Barnes 1986).

The between- and within-patch heterogeneity created by the overstory is reflected in the patterns of herbaceous plants in piñon-juniper woodlands, including north-south differences within canopy patches (Arnold 1964, Everett et al. 1983, Armentrout and Pieper 1988). These patterns have been attributed to microclimatic differences, but measures of overstory-imposed heterogeneity in microclimate were largely lacking.

Our study provides empirical support for models that treat semiarid woodlands and shrublands as a set of canopy and intercanopy patches (Walker et al. 1989, Mauchamp et al. 1994, Thiéry et al. 1995). The two patch types are differentiated by reduced inputs of solar radiation and moisture to the soil beneath woody canopies and are connected via canopy shading of inter- canopy areas, use of intercanopy water by woody plants, and, in some cases, redistribution of runoff from intercanopy to canopy locations. The proportions and spatial patterns of the two patch types are presumed to reflect ecological properties of herbaceous and woody plants (Milne et al. 1996). Predictions of vegetation dynamics in semiarid woodlands and shrublands may be improved through application of gap models, which have been successfully applied in both grasslands and forests (Shugart 1984, Coffin and Lauenroth 1989, 1990, 1994, Coffin and Urban 1993, Lauenroth et al. 1993). Horizontal heterogeneity in microclimate is likely to be more important in semiarid shrublands and woodlands than for sites with more homogeneous overstories at either end of the grassland-forest continuum, and may be particularly important to consider in evaluating population and community dynamics for a broader set of plant functional types (Coffin and Lauenroth 1990). Hence, the application of gap models to more heterogeneous semiarid sites may need to account for horizontal interactions between patch types, both aboveground (canopy shading of intercanopy patches and potential redistribution of intercanopy runoff to canopy patches) and belowground (use of shallow intercanopy water by woody plants). In addition, this spatial heterogeneity in microclimate between canopy and intercanopy patches may be important to consider in scaling up fluxes of water and energy for heterogeneous overstories (Goutorbe et al. 1994).

As we seek to apply our knowledge of nondegraded semiarid ecosystems to solving problems of land degradation, the importance of considering microclimatic differences between canopy and intercanopy patches becomes even more important. Differential impacts on canopy vs. intercanopy locations in degraded ecosystems have been documented for nutrients (Schlesinger et al. 1990, 1996); the net result is an increase in spatial heterogeneity of resources. However, to detect changes in heterogeneity associated with land use, we must first quantify the amount of spatial heterogeneity in nondegraded but heterogeneous sites, such as ours. Land uses such as grazing and off-road vehicle use can simultaneously reduce intercanopy herbaceous plant biomass and reduce infiltration capacity in intercanopies, thereby increasing intercanopy runoff and the potential for some of that runoff to be redistributed to canopy patches. Erosion in these systems can enter a feedback cycle, leading to further degradation (Wilcox et al. $1996 a, b$, Davenport et al. 1998). Hence, we concur that land degradation can be better understood by evaluating canopy and intercanopy differences (Grover and Musick 1990, Schlesinger et al. 1990); our results support extending that perspective to soil moisture and near-ground solar radiation.

Remediation strategies for degraded lands also differentially alter canopy and intercanopy areas, and there are probably interrelationships between their effectiveness and spatial impacts on microclimate. Ap- 
proaches to remediation include thinning of woody plants, adding a surface mulch to intercanopy areas, modifying soil surface microtopography, and seeding with herbaceous species. Thinning woody plants alters the soil moisture and solar radiation environment of the canopy patch: soil moisture in canopy patches increases and soil temperature differences between canopy and intercanopy are diminished (Everett and Sharrow 1985). Similarly, a surface mulch should reduce runoff from and soil temperatures in intercanopy soils. Microtopographic changes to the intercanopy surface should be beneficial to herbaceous plants, including benefits at the seedling establishment phase. Seeding in intercanopy patches with herbaceous species counteracts previous losses in seedling production and establishment. Land degradation problems in semiarid ecosystems, then, are related to differential impacts on canopy and intercanopy patches, and require consideration of how remediation alternatives affect these two patch types. Understanding the inherent spatial heterogeneity between canopy and intercanopy locations, and how that heterogeneity changes as sites become degraded, is a required step to arrive at effective prevention and mitigation of land degradation in semiarid ecosystems.

In summary, our results demonstrate how the spatial patterns of the overstory define predictable solar radiation and soil moisture patterns, effectively creating a variety of microclimatic zones that are of biological importance. Our results also contribute to bridging the gap between studies at either end of the grasslandforest continuum, and are highly relevant for understanding ecosystem processes in nondegraded and degraded semiarid shrublands and woodlands.

\section{ACKNOWLEDGMENTS}

We thank Clif Meyer, Susan Johnson, Katherine Dayem, Laura Campbell, Robert Lucero, Teng-Chiu Lin, Diana A. Heisler, Kathy E. Lee, and Chris Heil for research assistance John W. Nyhan for precipitation data; Mary Lu Breshears for editorial assistance; Shawki A. Ibrahim, William K. Lauenroth, and F. Ward Whicker for guidance; and Craig D. Allen, Christopher Field, Geoffrey M. Henebry, Bruce T. Milne, Bradford P. Wilcox, and an anonymous reviewer for their very helpful reviews. This work was supported by the Los Alamos National Environmental Research Park, Los Alamos National Laboratory Environmental Restoration Project, Kansas Applied Remote Sensing Program, the Kansas Biological Survey, and the University of Kansas Research Development and General Research Funds.

\section{Literature Cited}

Aguilera, M. O., and W. K. Lauenroth. 1995. Influence of gap disturbances and type of microsites on seedling establishment in Bouteloua gracilis. Journal of Ecology 83:8797.

Allen, C. D. 1989. Changes in the landscape of the Jemez Mountains, New Mexico. Dissertation. University of California, Berkeley, California, USA.

Armentrout, S. M., and R. D. Pieper. 1988. Plant distribution surrounding Rocky Mountain pinyon pine and oneseed juniper in south-central New Mexico. Journal of Range Management 41:139-143.
Arnold, J. F. 1964. Zonation of understory vegetation around a juniper tree. Journal of Range Management 17:41-42.

Baker, J. M., and R. R. Allmaras. 1990. System for automating and multiplexing soil moisture measurement by time-domain reflectometry. Soil Science Society of America Journal 54:1-6.

Barnes, F. J. 1986. Carbon gain and water relations in pinyon-juniper habitat types. Dissertation. New Mexico State University, Las Cruces, New Mexico, USA.

Becker, P., and A. P. Smith. 1990. Spatial autocorrelation of solar radiation in a tropical moist forest understory. Agricultural and Forest Meteorology 52:373-379.

Belsky, A. J., R. G. Amundson, J. M. Duxbury, S. J. Riha, A. R. Ali, and S. M. Mwonga. 1989. The effects of trees on their physical, chemical, and biological environments in a semi-arid savanna in Kenya. Journal of Applied Ecology 26:1005-1024.

Belsky, A. J., and C. D. Canham. 1994. Forest gaps and isolated savanna trees. BioScience 44:77-84.

Bowen, B. M. 1990. Los Alamos climatology. LA-11735MS; UC-902. National Technical Information Service, Springfield, Virginia, USA.

Breshears, D. D. 1993. Spatial partitioning of water use by herbaceous and woody lifeforms in semiarid woodlands. Dissertation. Colorado State University, Fort Collins, Colorado, USA.

Breshears, D. D., O. B. Myers, S. R. Johnson, C. W. Meyer, and S. N. Martens. 1997. Differential use of heterogeneous soil moisture by two semiarid woody species: Pinus edulis and Juniperus monosperma. Journal of Ecology 85:289299.

Canham, C. D., J. S. Denslow, W. J. Platt, J. R. Runkle, T. A. Spies, and P. S. White. 1990. Light regimes beneath closed canopies and tree-fall gaps in temperate and tropical forests. Canadian Journal of Forest Research 20:620-631.

Charley, J. L., and N. E. West. 1975. Plant-induced soil chemical patterns in some shrub-dominated semi-desert ecosystems of Utah. Journal of Ecology 63:945-963.

Clark, D. B., D. A. Clark, P. M. Rich, S. B. Weiss, and S. F. Oberbauer. 1996. Landscape-scale evaluation of understory light and canopy structure: methods and application in a neotropical lowland rain forest. Canadian Journal of Forest Research 26:747-757.

Coffin, D. P., and W. K. Lauenroth. 1989. Disturbances and gap dynamics in a semiarid grassland: a landscape-level approach. Landscape Ecology 3:19-27.

Coffin, D. P., and W. K. Lauenroth. 1990. A gap dynamics simulation model of succession in a semiarid grassland. Ecological Modelling 49:229-266.

Coffin, D. P., and W. K. Lauenroth. 1994. Successional dynamics of a semiarid grassland: effects of soil texture and disturbance size. Vegetatio 100:67-82.

Coffin, D. P., and D. L. Urban. 1993. Implications of natural history traits to system-level dynamics: comparisons of a grassland and a forest. Ecological Modelling 67:147-178.

Collings, M. R. 1966. Throughfall for summer thunderstorms in a juniper and pinyon woodland, Cibecue Ridge, Arizona. U.S. Geological Survey Professional Paper 485-B.

Cornet, A. F., C. Montana, J. P. Delhoume, and J. LopezPortillo. 1992. Water flow and the dynamics of desert vegetation stripes. Pages $327-345$ in A. J. Hansen and F. di Castri, editors. Landscape boundaries: consequences for biotic diversity and ecological flows. Springer-Verlag, New York, New York, USA.

Cressie, N. A. C. 1991. Statistics for spatial data. John Wiley and Sons, New York, New York, USA.

Davenport, D. W., D. D. Breshears, B. P. Wilcox, and C. D. Allen. 1998. Viewpoint: sustainability of pinyon-juniper ecosystems: a unifying perspective of soil erosion thresholds. Journal of Range Management: 51(2), in press. 
Davenport, D. W., B. P. Wilcox, and D. D. Breshears. 1996 Soil morphology of canopy and intercanopy sites in a piñon-juniper woodland. Soil Science Society of America Journal 60:1881-1887.

Dawson, T. E. 1993. Woodland water balance. Trends in Ecology and Evolution 8:120-121.

Eagleson, P. S., and R. I. Segarra. 1985. Water-limited equilibrium of savanna vegetation systems. Water Resources Research 21:1483-1493.

Emerson, F. W. 1932. The tension zone between grama grass and pinon-juniper associations in northeastern New Mexico. Ecology 13:347-358.

Everett, R. L., and S. H. Sharrow. 1985. Soil water and temperature in harvested and nonharvested pinyon-juniper stands. U.S. Forest Service Research Paper INT-342.

Everett, R. L., S. H. Sharrow, and R. O. Meeuwig. 1983. Pinyon-Juniper woodland understory distribution patterns and species associations. Bulletin of the Torrey Botanical Club 110:454-463.

Fortin, M.-J., P. Drapeau, and P. Legendre. 1989. Spatial autocorrelation and sampling design in plant ecology. Vegetatio 83:209-222.

Fournier, R. A., P. M. Rich, Y. R. Alger, V. L. Peterson, R. Landry, and N. M. August. 1995. Canopy architecture of boreal forests: links between remote sensing and ecology. Pages 225-235 in Proceedings of the American Society for Photogrammetry and Remote Sensing 1995 Annual Meeting, Charlotte, North Carolina. Volume 2. ASPRS, Sewickley, Pennsylvania, USA.

Frank, D. A., and R. S. Inouye. 1994. Temporal variation in actual evapotranspiration of terrestrial ecosystems: patterns and ecological implications. Journal of Biogeography 21: $401-411$.

Goutorbe, J.-P., T. Lebel, A. Tinga, P. Bessemoulin, J. Brouwer, A. J. Dolman, E. T. Engman, J. H. C. Gash, M. Hoepffner, P. Kabat, Y. H. Kerr, B. Monteny, S. Prince, F. Said, P. Sellers, and J. S. Wallace. 1994. HAPEX-Sahel: a largescale study of land-atmosphere interactions in the semiarid tropics. Annales Geophysicae 12:53-64.

Grover, H. D., and H. B. Musick. 1990. Shrubland encroachment in southern New Mexico, U.S.A.: an analysis of desertification processes in the American Southwest. Climatic Change 17:305-330.

Joffre, R., and S. Rambal. 1988. Soil water improvement by trees in the rangelands of southern Spain. Oecologia Plantarum 9:405-422.

Joffre, R., and S. Rambal. 1993. How tree cover influences the water balance of Mediterranean rangelands. Ecology 74:570-582.

Johnsen, T. N., Jr. 1962. One-seed juniper invasion of northern Arizona grasslands. Ecological Monographs 32:187207.

Kintigh, R. G. 1949. Some effects of temperature on germination and development of pinyon pine. Journal of Forestry 47:622-626.

Lajtha, K., and F. J. Barnes. 1991. Carbon gain and water use in pinyon pine-juniper woodlands of northern New Mexico: field versus phytotron chamber measurements. Tree Physiology 9:59-67.

Lajtha, K., and J. Getz. 1993. Photosynthesis and water-use efficiency in pinyon-juniper communities along an elevation gradient in northern New Mexico. Oecologia 94:95101.

Lauenroth, W. K., D. L. Urban, D. P. Coffin, W. J. Parton, H. H. Shugart, T. B. Kirchner, and T. M. Smith. 1993. Modeling vegetation structure-ecosystem process interactions across sites and ecosystems. Ecological Modelling 67:4980.

Legendre, P. 1993. Spatial autocorrelation: trouble or new paradigm? Ecology 74:1659-1673.
Legendre, P., and M.-J. Fortin. 1989. Spatial pattern and ecological analysis. Vegetatio 80:107-138.

Lin, T., P. M. Rich, D. A. Heisler, and F. J. Barnes. 1992. Influences of canopy geometry on near-ground solar radiation and water balances of pinyon-juniper and ponderosa pine woodlands. Pages 285-294 in Proceedings of the American Society for Photogrammetry and Remote Sensing 1992 Annual Meeting, Albuquerque, New Mexico. ASPRS, Sewickley, Pennsylvania, USA.

Ludwig, J. A., and D. J. Tongway. 1995. Desertification in Australia: an eye to grass-roots and landscapes. Environmental Monitoring and Assessment 37:231-237.

Martens, S. N., D. D. Breshears, C. W. Meyer, and F. J. Barnes. 1997. Scales of above- and below-ground competition in a semiarid woodland detected from spatial pattern. Journal of Vegetation Science 7, in press.

Martinez-Meza, E., and W. G. Whitford. 1996. Stemflow, throughfall and channelization of stemflow by roots in three Chihuahuan desert shrubs. Journal of Arid Environments 32:271-287.

Mauchamp, A., S. Rambal, and J. Lepart. 1994. Simulating the dynamics of a vegetation mosaic: a spatialized functional model. Ecological Modelling 71:107-130.

Milne, B. T., A. R. Johnson, T. H. Keitt, C. A. Hatfield, J. David, and P. T. Hraber. 1996. Detection of critical densities associated with piñon-juniper woodland ecotones. Ecology 77: 805-821.

Neilson, R. P. 1986. High-resolution climatic analysis and southwest biogeography. Science 232:27-34.

Neilson, R. P., G. A. King, and G. Koerper. 1992. Toward a rule-based biome model. Landscape Ecology 7:27-43.

Newman, B. D., A. R. Campbell, and B. P. Wilcox. 1997. Tracer-based studies of soil water movement in semi-arid forests of New Mexico. Journal of Hydrology, in press.

Nyhan, J. W., L. W. Hacker, T. E. Calhoun, and D. L. Young. 1978. Soil survey of Los Alamos County, New Mexico. LA-6779-MS; UC-11. National Technical Information Service, Springfield, Virginia, USA.

Nyhan, J. W., T. E. Hakonson, and B. J. Drennon. 1990. A water balance study of two landfill cover designs for semiarid regions. Journal of Environmental Quality 19:281288.

Padien, D. J., and K. Lajtha. 1992. Plant spatial pattern and nutrient distribution in pinyon-juniper woodlands along an elevational gradient in northern New Mexico. International Journal of Plant Science 153:425-433.

Pierson, F. B., and J. R. Wight. 1991. Variability of nearsurface soil-temperature on sagebrush rangeland. Journal of Range Management 44:491-497.

Rich, P. M. 1989. A manual for analysis of hemispherical canopy photography. Los Alamos National Laboratory Report LA-11733-M, Los Alamos, New Mexico, USA.

. 1990. Characterizing plant canopies with hemispherical photography. In N. S. Goel and J. M. Norman, editors. Instrumentation for studying vegetation canopies for remote sensing in optical and thermal infrared regions. Remote Sensing Reviews 5:13-29.

1997. Biophysical considerations for an integrative model of pinyon juniper woodlands. In S. N. Martens and P. M. Rich, editors. Proceedings of the 1994 Workshop on Integrative Modeling of Pinyon-Juniper Woodlands. Los Alamos National Laboratory Report, Los Alamos, New Mexico, USA, in press.

Rich, P. M., D. B. Clark, D. A. Clark, and S. F. Oberbauer. 1993a. Long-term study of solar radiation regimes in a tropical wet forest using quantum sensors and hemispherical photography. Agricultural and Forest Meteorology 65: 107-127.

Rich, P. M., W. A. Hetrick, S. C. Saving. 1995. Modeling topographic influences on solar radiation: a manual for the 
SOLARFLUX model. Los Alamos National Laboratory Report LA-12989-M. Los Alamos, New Mexico, USA.

Rich, P. M., G. S. Hughes, and F. J. Barnes. 1993b. Using GIS to reconstruct canopy architecture and model ecological processes in pinyon-juniper woodlands. Pages 435445 in Thirteenth Annual Environmental Systems Research Institute User Conference. Volume 2. Environmental Systems Research Institute, Redlands, California, USA.

Ritchie, J. T. 1972. Model for predicting evaporation from a row crop with incomplete cover. Water Resources Research 8:1204-1213.

Sala, O. E., W. K. Lauenroth, W. J. Parton, and M. J. Trlica. 1981. Water status of soil and vegetation in a shortgrass steppe. Oecologia (Berlin) 48:327-331.

Schlesinger, W. H., J. A. Raikes, A. E. Hartley, and A. F. Cross. 1996. On the spatial pattern of soil nutrients in desert ecosystems. Ecology 77:364-374.

Schlesinger, W. H., J. F. Reynolds, G. L. Cunningham, L. F. Huenneke, W. M Jarrell, R. A. Virginia, and W. G. Whitford. 1990. Biological feedbacks in global desertification. Science 247:1043-1048

Seyfried, M. S., and B. P. Wilcox. 1995. Scale and the nature of spatial variability: field examples having implications for hydrologic modeling. Water Resources Research 31: 173-184.

Sharpe, P. J. H., J. Walker, L. K. Penridge, H.-I. Wu, and E. J. Rykiel, Jr. 1986. Spatial considerations in physiological models of tree growth. Tree Physiology 2:403-421.

Shugart, H. H. 1984. A theory of forest dynamics. SpringerVerlag, New York, New York, USA.

Skau, C. M. 1964. Interception, throughfall, and stemflow in Utah and alligator juniper cover types in northern Arizona. Forest Science 10:283-287.

Sokal, R. R. 1979. Ecological parameters inferred from spatial correlograms. Pages 167-196 in G. P. Patil and M. L. Rosenzweig, editors. Contemporary quantitative ecology and related ecometrics. Statistical ecology series, Volume 12. International Co-operative Publishing House, Fairland, Maryland, USA.

Sokal, R. R., and N. L. Oden. 1978. Spatial autocorrelation in biology 1. Methodology. Biological Journal of the Linnean Society 10:199-228.

Stephenson, N. L. 1990. Climatic control of vegetation distribution: the role of water balance. American Naturalist 135:649-670.
Thiéry, J. M., J.-M. D’Herbès, and C. Valentin. 1995. A model simulating the genesis of banded vegetation patterns in Niger. Journal of Ecology 83:497-507.

Topp, G. C., J. L. Davis, and A. P. Annan. 1980. Electromagnetic determination of soil water content: measurements in coaxial transmission lines. Water Resources Research 16:574-582.

Topp, G. C., and J. L. Davis. 1985. Measurement of soil water content using time-domain reflectrometry (TDR): a field evaluation. Soil Science Society of America Journal 49:19-24.

Walker, J., P. J. H. Sharpe, L. K. Penridge, and H. Wu. 1989. Ecological field theory: the concept and field tests. Vegetatio 83:81-95.

Walter, H. 1971. Ecology of tropical and subtropical vegetation. Oliver and Boyd, Edinburgh, UK.

Wilcox, B. P. 1994. Runoff and erosion in intercanopy zones of pinyon-juniper woodlands. Journal of Range Management 47:285-295.

Wilcox, B. P., C. D. Allen, B. D. Newman, K. D. Reid, D. Brandes, J. Pitlick, and D. W. Davenport. 1996a. Runoff and erosion on the Pajarito Plateau: observations from the field. Pages 433-439 in New Mexico Geological Society Guidebook: $4^{\text {th }}$ Field Conference, Jemez Mountains Region, 1996. New Mexico Geological Society Guidebook, Albuquerque, New Mexico, USA.

Wilcox, B. P., and D. D. Breshears. 1995. Hydrology and ecology of pinyon-juniper woodlands: conceptual framework and field studies. Pages 109-119 in Proceedings: Desired Future Conditions for Pinyon-juniper Ecosystems. USDA Forest Service General Technical Report RM-258.

Wilcox, B. P., J. Pitlick, C. D. Allen, and D. W. Davenport. $1996 b$. Runoff and erosion from a rapidly eroding pinyonjuniper hillslope. Pages 61-77 in M. G. Anderson and S. M. Brooks, editors. Advances in hillslope processes. Volume 1. John Wiley \& Sons, New York, New York, USA.

Yeakley, J. A., R. A. Moen, D. D. Breshears, and M. K. Nungesser. 1994. Response of North American ecosystem models to multi-annual periodicities in temperature and precipitation. Landscape Ecology 9:249-260.

Young, J. A., and R. A. Evans. 1987. Stem flow on western juniper (Juniperus occidentalis) trees. Pages 373-381 in Proceedings-Pinyon-Juniper Conference, USDA Forest Service Intermountain Research Station General Technical Report INT215. 